\title{
Applications of Zymography (Substrate-SDS-PAGE) for Peptidase Screening in a Post-Genomic Era
}

\author{
Claudia M. d'Avila-Levy¹, André L. S. Santos², Patrícia Cuervo1, \\ José Batista de Jesus ${ }^{1,3}$ and Marta $\mathrm{H}$. Branquinha ${ }^{2}$ \\ ${ }^{1}$ Instituto Oswaldo Cruz, Fundação Oswaldo Cruz, Rio de Janeiro \\ ${ }^{2}$ Departamento de Microbiologia Geral, Instituto de Microbiologia Paulo de Góes, \\ Universidade Federal do Rio de Janeiro, Rio de Janeiro \\ ${ }^{3}$ Universidade Federal de São João Del Rei, São João Del Rei \\ Brazil
}

\section{Introduction}

Peptidases are enzymes that catalyze the hydrolysis of peptide bonds in proteins or peptides. The hydrolysis can be specific or unspecific, leading to highly regulated cleavage of specific peptide bonds, or to complete degradation of proteins to oligopeptides and/or amino acids. Peptidases can be classified as endo- or exopeptidases, the latter only act near the ends of the polypeptide chain. Endopeptidases are divided into six major families by virtue of the specific chemistry of their active site: aspartic, serine, metallo-, cysteine, glutamic and threonine peptidases (Rawlings et al. 2010).

Zymography is an electrophoretic technique, based on sodium dodecyl sulfate polyacrylamide gel electrophoresis (SDS-PAGE) and a substrate (e.g. gelatin, casein, albumin, hemoglobin, etc.) co-polymerized with the polyacrylamide matrix. Proteins are prepared by the standard SDS-PAGE buffer under non-reducing conditions (no boiling and no reducing agent), and are separated by molecular mass in the standard denaturing SDSPAGE co-polymerized with a protein substrate. After electrophoresis, peptidases are renatured by the removal of the denaturing SDS by a non-ionic detergent, such as Triton X100, followed by incubation in conditions specific for each peptidase activity (time, temperature, ions, ionic strength), when the enzymes hydrolyze the embedded substrate, then proteolytic activity can be visualized as cleared bands on a Coomassie stained background (Heussen and Dowdle, 1980). Therefore, only endopeptidases can be detected by substrate-SDS-PAGE, which requires a considerable degradation of the substrate for visualization of the degradation haloes. Alternatively, an overlay with specific chromogenic or fluorogenic peptide substrate can be done after SDS-PAGE separation of the proteins and renaturation with Triton X-100, which allows the detection of specific peptidases in complex biological samples.

This technique has many benefits: (1) it is relatively inexpensive, requires short assaying times, and peptidases with distinct molecular masses can be detected on a single gel; 
separation of proteins by molecular mass through non-reducing electrophoretic migration allows a presumptive correlation with known peptidases; (3) incubation with proteolytic inhibitors provides powerful information about enzyme classification; (4) $\mathrm{pH}$ and temperature changes help to assess peptidase characteristics; (5) several substrates can be co-polymerized to assess peptidase degradation capacity; (6) densitometry can be used for quantitative analysis. Ultimately, in organisms with complete genome sequences, bioinformatic analysis provides rich information on putative peptidases, such as: peptidase classification, approximated molecular mass, possible cellular localization through classical motifs, evolutionary and functional relationships, and so on. However, it cannot be ascertained if the described ORFs are indeed expressed and active. Therefore, a zymographic assay coupled with bioinformatic analysis may allow the detection of functionally active enzymes.

The advantages of this technique are exemplified by its application nowadays to unveil peptidases in biological systems, which possesses genome information, but still zymography is the method of choice for peptidase screening, identification and characterization. Wilder and colleagues, for instance, report that zymography can selectively distinguish cathepsins $\mathrm{K}, \mathrm{L}, \mathrm{S}$ and V in cells and tissues by its electrophoretic mobility and by simply manipulating substrate and $\mathrm{pH}$. The sequence homology among these cathepsins leads to a substrate promiscuity, which precludes desired specificity for in solution assays with specific chromogenic or fluorogenic peptide substrate (Wilder et al. 2011). Zymography allows the detection of a $37 \mathrm{kDa}$ (cathepsin K), $35 \mathrm{kDa}$ (cathepsin V), $25 \mathrm{kDa}$ (cathepsin S) and $20 \mathrm{kDa}$ (cathepsin L). Cathepsin $\mathrm{K}$ activity disappeared and $\mathrm{V}$ remained when incubated at $\mathrm{pH} 4.0$ instead of 6.0, allowing the visualization of each enzyme (Wilder et al. 2011). Kupai and colleagues also highlighted that substrate zymography is the method of choice, among several analyzed, to detect the activity of the different matrix metallopeptidase (MMP) isoenzymes from a wide range of biological samples (Kupai et al. 2010). Also, it allows high throughput screening of specific MMP inhibitors, especially because the nature of the residues in the enzyme's active site is highly conserved among the different MMPs, therefore, once again, in solution enzymatic assays are not applicable (Devel et al. 2006, Kupai et al. 2010). Also, for the screening of tissue inhibitors of metallopeptidases (TIMPs), reverse zymography is a powerful approach. This technique is based on the ability of the inhibitors to block gelatinase activity of a MMP, usually MMP-2. A calibrated solution of gelatinase-A (MMP-2) is co-polymerized with gelatin in the polyacrylamide gel. The samples possibly containing TIMPs are then separated by electrophoresis, SDS is removed and the gel is incubated in a buffer that allows the gelatinase to digest the gelatin, except where it is inhibited by TIMP proteins. After staining with Coomassie blue, the result is a gel with a pale blue background (where gelatin was degraded by the gelatinase) with blue bands showing the positions and relative amounts of TIMPs (Snoek-van Beurden and Von den Hoff, 2005).

In view of this, below we will present comments on peptidase screening through zymography discussing possible protocol variations and its implications, and then we present and discuss practical examples of the application of zymography to generate critical data in organisms that still do not possess genome information. Finally, we will discuss the possibility of direct peptidase identification through two-dimensional zymography coupled to mass spectrometry. 


\section{Comments on peptidase screening through substrate-SDS-PAGE}

Several research groups perform substrate-SDS-PAGE to assess, screen and characterize peptidases in complex or purified biological preparations. After the original publication from Heussen and Dowdle (1980), several adaptations have been implemented to improve the detection of a specific peptidase class. Below we will present a generalized protocol indicating possible variations.

\subsection{Sample homogenization}

The preparation of the biological sample is critical for the success of the zymography, all the procedure must be performed at $4{ }^{\circ} \mathrm{C}$, the addition of detergents such as Triton $\mathrm{X}-100$, SDS or CHAPS (3-[(3-cholamidopropyl)dimethylammonio]-1-propanesulfonate) for the solubilization and recovery of hydrophobic enzymes is necessary, if one is interested in such enzymes, also addition of proteolytic inhibitors to undesired peptidase classes is also an interesting strategy. Alternatively, the separation of hydrophobic from hydrophilic proteins can be achieved during phase partition in solutions of Triton X-114, which occurs at $37^{\circ} \mathrm{C}$ preserving enzyme integrity (Figure 1) (Bouvier et al. 1987). After sample preparation, SDSPAGE sample buffer is added to the biological sample $(62.5 \mathrm{mM}$ Tris $\mathrm{HCl}, \mathrm{pH} 6.8,2 \%$ SDS, $10 \%$ (v/v) glycerol, and $0.002 \%$ bromophenol blue). A concentrated sample buffer can be used to avoid sample dilution, which is critical for the detection of low abundant enzymes. The proteins are not denatured since sample is kept at $4{ }^{\circ} \mathrm{C}$, there is no sample boiling, nor the addition of reducing agents such as dithiothreitol (DTT) or 2-mercaptoethanol, as usual in sample preparation for standard SDS-PAGE analysis. The sample must maintain its native form due to the the further step of substrate degradation.

\subsection{Polyacrylamide gels containing sodium dodecyl sulfate and co-polymerized substrates}

Here, to the standard Laemmli protocol (Laemmli, 1970), a substrate can be co-polymerized to the gel (Heussen and Dowdle, 1980). Alternatively, an overlay with fluorogenic or chromogenic peptide substrates can be done (Cadavid-Restrepo et al. 2011). The acrylamide concentration in gels varies more commonly from 7 to $15 \%$, which impact on protein separation; low molecular mass proteins usually require higher acrylamide concentration for better protein resolution. The co-polymerized substrate can be virtually any protein. Gelatin is commonly used as a protein substrate because it is easily hydrolyzed by several peptidases and does not tend to migrate out of the resolving gel in electrophoretic tests performed at $4^{\circ} \mathrm{C}$, and is inexpensive (Michaud et al. 1996). In addition to gelatin, several other proteins have been used, such as: casein, bovine serum albumin, human serum albumin, hemoglobin, mucin, immunoglobulin, and collagen (d'Avila-Levy et al. 2005; Pereira et al. 2010a). Also, complex mixtures of proteins can be used, which may reflect a functional role of the enzyme. For instance, our research group employed gut proteins from an insect to co-polymerize in acrylamide gels. Then, extracts from a protozoan believed to interact with the insect gut were assayed, revealing the peptidases capable of degrading the insect gut proteins (Pereira et al. 2010a). An example of zymographies performed with a set of eight distinct proteinaceous substrates, as well as, a densitometric measure of the degradation halos can be seen in Figure 2. 


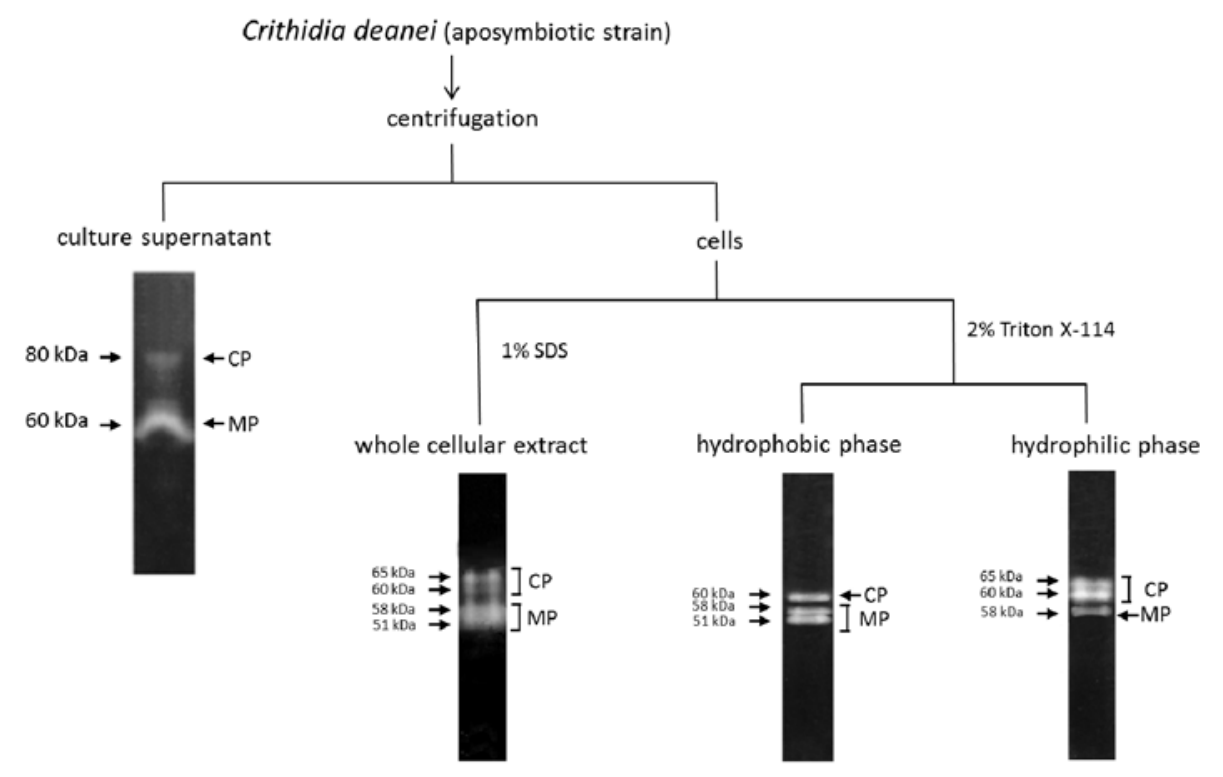

Fig. 1. Extracellular and cell-associated proteolytic enzymes of Crithidia deanei cells, an insect trypanosomatid. Parasites were cultured in a complex medium (brain heart infusion) for 48 $\mathrm{h}$ at $28^{\circ} \mathrm{C}$. Then, cells were harvested by centrifugation, the culture supernatant was filtered in Millipore membrane $0.22 \mu \mathrm{m}$ and concentrated 50-fold by dialysis (cut-off $9000 \mathrm{Da}$ ) against polyethylene glycol 4000 overnight at $4{ }^{\circ} \mathrm{C}$. The cells were lysed by: the addition of SDS, generating whole cellular extract, or by Triton X-114 to obtain the hydrophilic (cytoplasmatic and intravesicular fraction) and hydrophobic (membrane fraction) phases. The extracellular and cellular extracts were applied on gelatin-SDS-PAGE to evidence the proteolytic enzymes. The gels were incubated in $50 \mathrm{mM}$ sodium phosphate buffer $\mathrm{pH} 5.5$ supplemented with DTT $2 \mathrm{mM}$ at $37^{\circ} \mathrm{C}$ for $24 \mathrm{~h}$. MP, metallopeptidase and CP, cysteine peptidase. For experimental details see d'Avila-Levy et al. 2001, 2003.

\subsection{Enzyme renaturation and proteolysis}

After electrophoresis, the enzymes are renaturated by replacement of the anionic detergent SDS by the non-ionic detergent Triton X-100, through gel washing. Then, gels are incubated under conditions ideal for detection of the desired peptidase. For instance, metallopeptidases are known to require neutral to basic $\mathrm{pH}$ for activity, while cysteine peptidases require an acidic $\mathrm{pH}$ and a reducing agent, usually DTT (Branquinha et al. 1996). However, it is common to screen biological samples, where there is no previous clue on what peptidase class shall be present, nor the best conditions for proteolysis. Therefore, it is necessary to assess several parameters, such as incubation time, $\mathrm{pH}$, temperature, influence 
of ions or reducing agents and finally assess the inhibition profile. A general flowchart for establishing such conditions is shown in Figure 3, and a general view of Gelatin-SDS-PAGE screening in an uncharacterized organism can be seen in Figure 4.

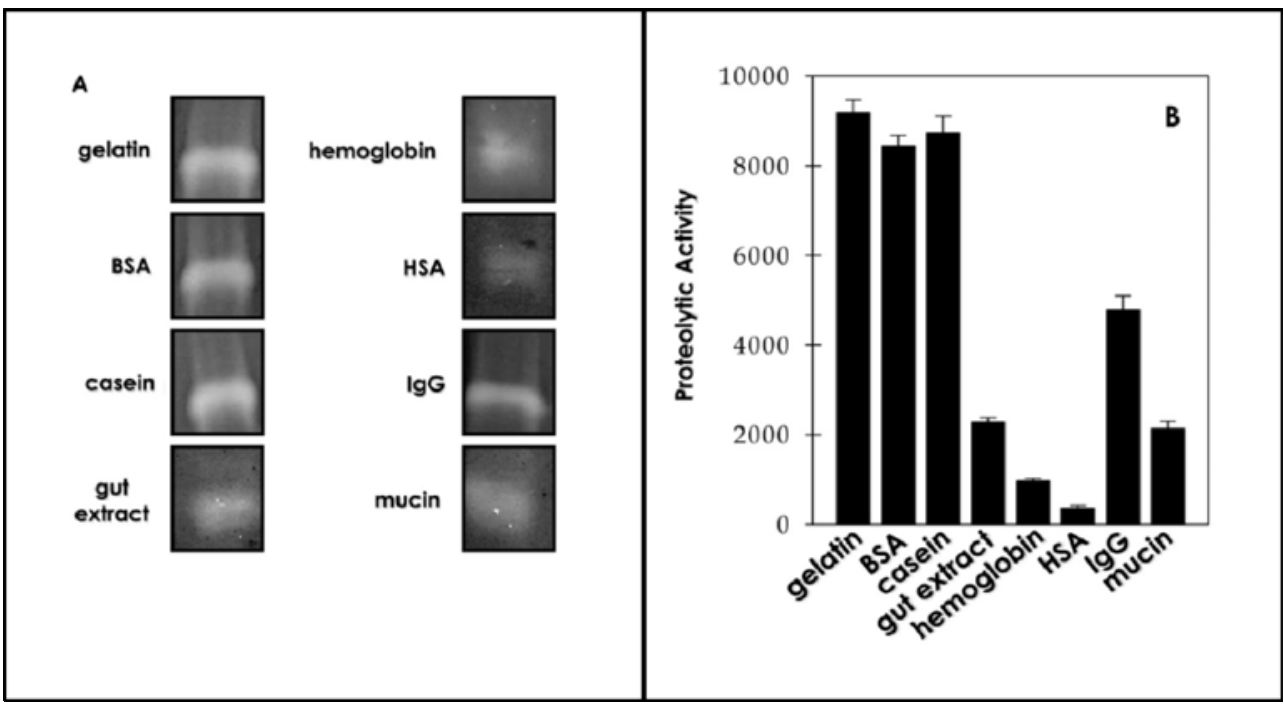

Fig. 2. Degradation of different proteinaceous substrates co-polymerized to SDS-PAGE by a surface metallopeptidase from Herpetomonas samuelpessoai, an insect trypanosomatid. The following substrates were individually incorporated into SDS-PAGE to evidence the proteolytic activity: gelatin, bovine serum albumin, human serum albumin, casein, immunoglobulin G (IgG), hemoglobin, mucin and gut extract from Aedes aegypti. The gels were incubated for $20 \mathrm{~h}$ at $37 \circ \mathrm{C}$ in $50 \mathrm{mM}$ sodium phosphate buffer $\mathrm{pH} 6.0$ supplemented with DTT $2 \mathrm{mM}$ (A). The degradation halos, which correlate with degradation capability, were densitometric measured and expressed as arbitrary units of proteolytic activity (B). For experimental details see Pereira et al. 2010b. Reprinted with permission of Protist.

\section{Practical examples of peptidases screening through SDS-PAGE-substrate}

\subsection{A first glance on Bodo sp. peptidases}

Bodo sp. is a free-living flagellate that belongs to the family Bodonidae, order Kinetoplastida. This bodonid isolate still has its taxonomic position unsolved, but it is phylogenetically related to Bodo caudatus and Bodo curvifilus, which are considered ancestral to the trypanosomatids. The Trypanosomatidae family comprises parasites that are of particular interest due to their medical importance, such as the etiologic agent of Chagas' disease (Trypanosoma cruzi), African trypanosomiasis (Trypanosoma brucei complex) and the various forms of leishmaniasis caused by Leishmania spp.. Due to their medical relevance, this family has been the focus of extensive research (Wallace, 1966; Vickerman, 1994). Peptidase characterization in Bodo sp. and comparison to peptidases from closely related pathogenic protozoa may help to understand peptidase function and evolution in general. The gold standard approach for such comparison would be a bioinformatic analysis of the Bodo 


\section{Flowchart for Peptidase Screening}

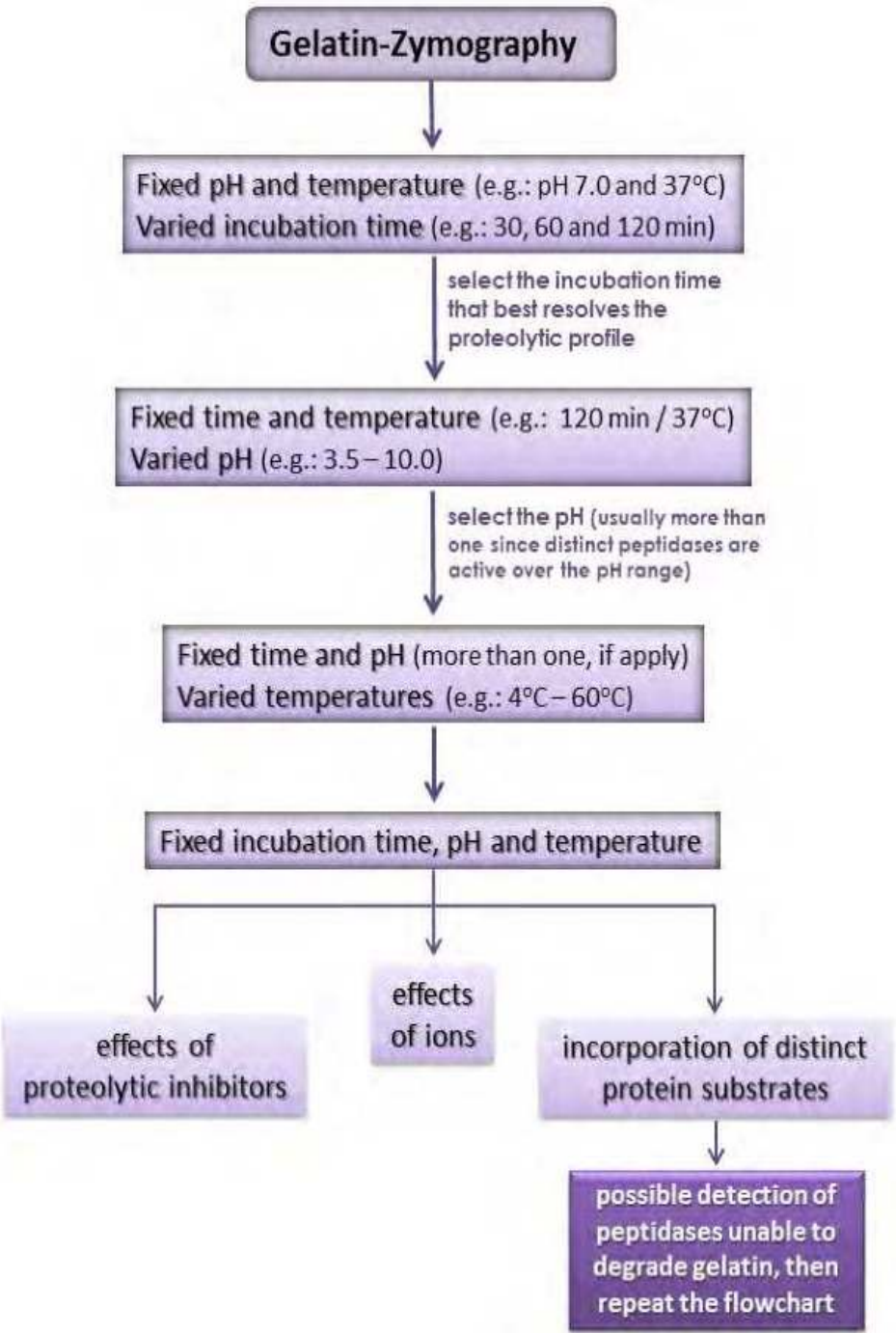

Fig. 3. Flowchart for peptidase screening. Several parameters must be assessed to resolve the proteolytic profile in an unknown biological sample. This scheme represents a suggestion of a step-by-step analysis of these parameters, which are: amount of sample, incubation time, $\mathrm{pH}$, temperature, effect of ions, effect of reducing agents, effect of peptidase inhibitors, and ability to degrade distinct proteinaceous substrates. Usually, gelatin is the proteinaceous substrate of choice for initial screening because it is easily hydrolyzed by several peptidases, 
does not tend to migrate out of the resolving gel and is inexpensive, then with an arbitrary $\mathrm{pH}$ and temperature (usually neutral $\mathrm{pH}$ at $37 \mathrm{o}^{\circ}$ ), the incubation time is varied from minutes to even $72 \mathrm{~h}$, depending on the sample. After selecting the incubation time that allows the detection of the higher number of enzymes without band overlapping, variations on the $\mathrm{pH}$ allows the determination of this biochemical characteristic of each band. After this assay, the peptidase(s) of interest can be tested over a range of temperatures, ions, reducing agents or proteolytic inhibitors. Finally, distinct proteinaceous substrates can be co-polymerized to the gels, revealing either the ability of the detected peptidases to degrade other substrates, which ultimately gives a glance on peptidase function, or even revealing enzymes not capable of degrading gelatin (see figure 2). The proper combination of these parameters may reveal interesting enzymes, such as peptidases strictly dependable on metal ions, stimulated by reducing agents, active only at acidic or alkaline conditions and so on.

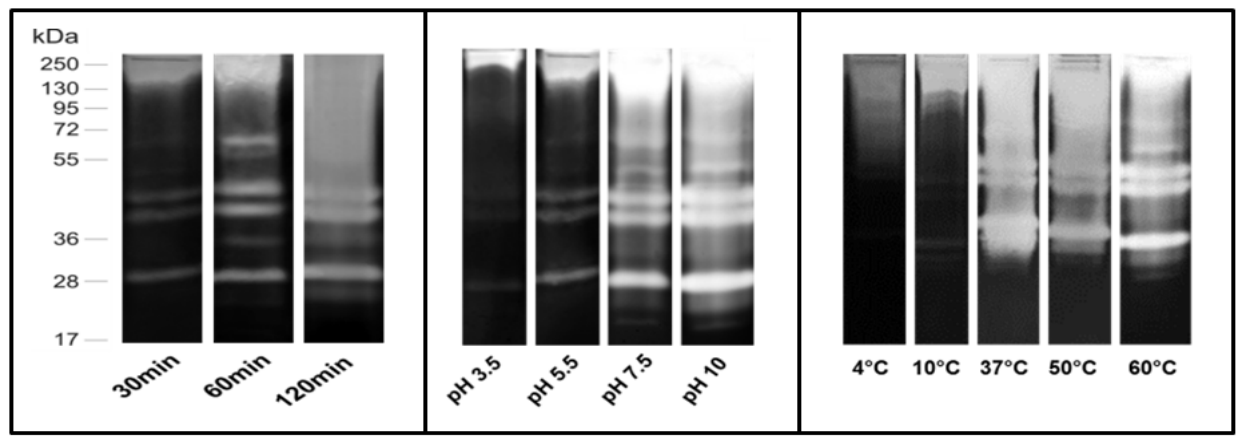

Fig. 4. Gelatin-SDS-PAGE screening of peptidases in homogenates from Aedes albopictus pupa. The following parameters were assessed: incubation time, $\mathrm{pH}$ and temperature. Peptidase activities were detected after incubation of the gels for 30,60 or $120 \mathrm{~min}$ at $37 \mathrm{\circ}^{\circ} \mathrm{C}$ in $100 \mathrm{mM}$ Tris- $\mathrm{HCl}$ buffer $\mathrm{pH}$ 7.5. The numbers on the left indicate apparent molecular masses of the active bands expressed on kiloDaltons (kDa). Afterwards, 60 min incubation was selected and the gels were incubated in reaction buffer containing $100 \mathrm{mM}$ sodium acetate at $\mathrm{pH} 3.5$ or 5.5 or $100 \mathrm{mM}$ Tris- $\mathrm{HCl}$ at $\mathrm{pH} 7.5$ or 10.0. Finally, the effect of temperature on the proteolytic activities was assayed by incubating of the gels for $60 \mathrm{~min}$ at $4,10,37,50$ or $60^{\circ} \mathrm{C}$ in reaction buffer containing $100 \mathrm{mM}$ Tris- $\mathrm{HCl}$ at $\mathrm{pH} 7.5$. Saboia-Vahia et al. unpublished data.

genome coupled to more defined biochemical characterization of individual peptidases. However, in the absence of a Bodo genome, we have employed substrate-SDS-PAGE to assess peptidases in this bodonid, which presents serine peptidases ranging from 250 to 75 $\mathrm{kDa}$, with a slight preference for acidic $\mathrm{pH}$. This finding is dissimilar to what has been described in related pathogenic protozoa (Figure 5) (d'Avila-Levy et al., 2009). Curiously, all the analyzed closely related parasitic trypanosomatids, as well, as Cryptobia salmonistica, reveal through gelatin-SDS-PAGE only metallo- and cysteine peptidases, which are prototypal peptidases and virulence factors. In trypanosomatids, for instance, serine peptidases can only be detected by in-solution assays or after enrichment processes (Grellier et al. 2001). It is somewhat intriguing that cysteine and metallopeptidases are either not resistant to the denaturation/refold process and/or are not abundantly expressed by this 
free living bodonid, because they were not detected by zymography. This may reflect substantial differences among the peptidases from these organisms. The raw data revealed by susbtrate-zymography provided the first observation on possible differences in peptidase profile among the families Bodonidae, Trypanosomatidae, and Cryptobiidae, forming the basis for future research.

\section{Bodo sp.(cellular extract)}

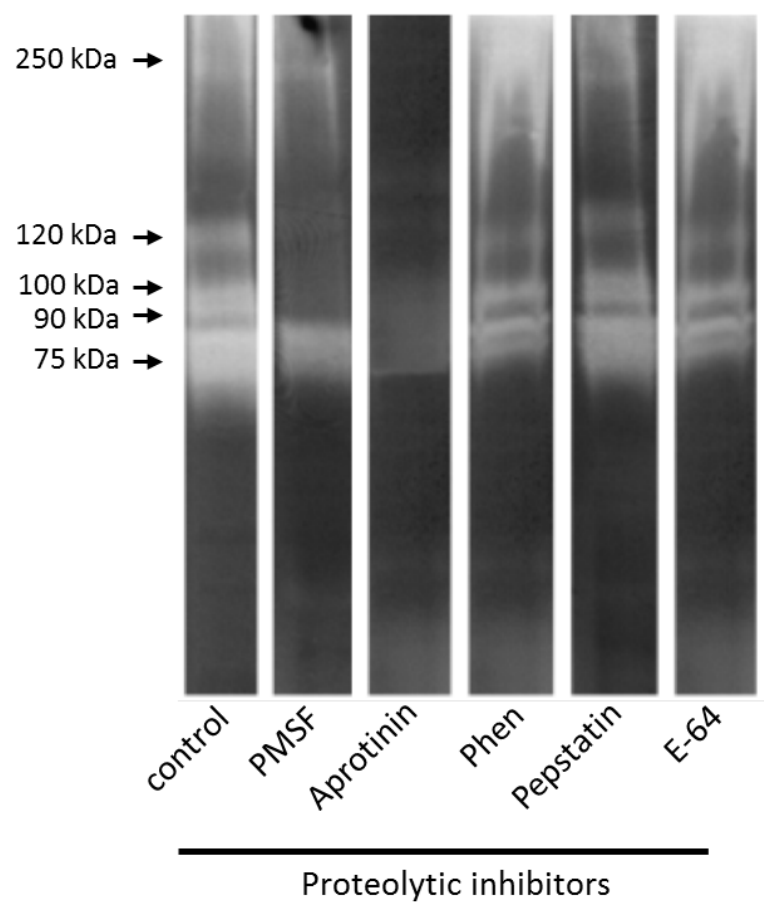

Fig. 5. Inhibition profile of cellular peptidases of Bodo sp. in gelatin-SDS-PAGE. In order to determine the enzymatic class, after electrophoresis, the gels were incubated for $48 \mathrm{~h}$ at $28^{\circ} \mathrm{C}$ in 50mM phosphate buffer $\mathrm{pH} 5.5$ in the absence (control) or in the presence of the following proteolytic inhibitors: $1 \mathrm{mM}$ phenylmethylsulfonyl fluoride (PMSF), $1 \mathrm{mg} / \mathrm{ml}$ aprotinin, $10 \mathrm{mM}$ 1,10-phenanthroline (Phen), $1 \mathrm{mM}$ pepstatin A, or $10 \mu \mathrm{M}$ trans-epoxysuccinyl L-leucylamido-(4-guanidino) butane (E-64). Numbers on the left indicate relative molecular mass of the peptidases. For experimental details see d'Avila-Levy et al. 2009. Reprinted with permission of The Journal of Eukaryotic Microbiology.

\subsection{Identification of peptidases in Herpetomonas spp. and possible biological functions proposed by overlay gel approaches}

In addition to the heteroxenic parasites that are of particular interest in the Trypanosomatidae family due to their medical importance, several genera are composed of monoxenic parasites of the gut of a wide range of insects. The Herpetomonas genus is composed of insect trypanosomatids that display promastigote, paramastigote and 
opisthomastigote developmental stages during its life cycle (McGhee and Cosgrove, 1980), being used as a model to study the complex events of cell differentiation process. Also, these traditionally "non-mammalian and non-pathogenic" microorganisms have been used as experimental models of the Trypanosomatidae family for exploring their basic mechanisms at the genetic, physiological, ultrastructural and biochemical levels. In the same way, several research groups have described common structures/molecules produced by monoxenous and heteroxenous parasites belonging to the Trypanosomatidae family (Lopes et al. 1981; Breganó et al. 2003; Santos et al. 2006, 2007; Elias et al. 2008). Interestingly, Herpetomonas species have been detected not only in insects, but repeatedly in plants and mammals, including immunosuppressed humans, mainly in HIV-infected individuals, in whom the parasites caused either visceral or cutaneous lesions (reviewed by Chicharro and Alvar, 2003; Morio et al. 2008), showing the ability to develop digenetic life style under certain conditions. Collectively, these studies emphasize the need for further investigation in the biochemical machinery of these intriguing insect trypanosomatids.

Whole cellular extracts of $H$. samuelpessoai promastigotes when analyzed by gelatin-SDSPAGE revealed two major peptidase classes: a prominent metallopeptidase of $66 \mathrm{kDa}$ (actually a broad hydrolytic activity ranging from 60 to $80 \mathrm{kDa}$ ), inhibited by $10 \mathrm{mM} \mathrm{1,10-}$ phenanthroline, and a minor cysteine peptidase activity of $45 \mathrm{kDa}$, restrained by $1 \mu \mathrm{M} \mathrm{E}-64$ and leupeptin (Santos et al. 2003).

The $66 \mathrm{kDa}$ metallopeptidase activity was detected in the parasite membrane fraction after Triton X-114 partition (Etges, 1992; Schneider and Glaser, 1993; Santos et al. 2003) or after treatment of living cells with phospholipase C (Santos et al. 2002; Santos et al. 2006) as well as in the extracellular environment as the major secreted peptidase component (Santos et al. 2001, 2003, 2006; Elias et al. 2006). This metallopeptidase produced by H. samuelpessoai cells shares common biochemical and immunological properties (Elias et al. 2006; Santos et al. 2006) with the major metallopeptidase expressed by Leishmania species, called leishmanolysin or gp63, a virulence factor that participates in different stages of the parasite life cycle such as adhesion and escape from host immune response (Yao, 2010). The incorporation of different proteinaceous substrates into SDS-PAGE demonstrated that leishmanolysin-like molecule from $H$. samuelpessoai was able to degrade hemoglobin, casein, immunoglobulin G, mucin, human and bovine albumins as well as the gut protein extract from Aedes aegypti (Figure 2) (Pereira et al. 2010a), an experimental model to study the trypanosomatids-insect interplay (reviewed by Santos et al. 2006), culminating in the generation of peptides and amino acids required for parasite growth and development, as well as it might cleave structural barriers in order to improve its dissemination. Also, the $\mathrm{pH}$ dependence of the $66 \mathrm{kDa}$ metallopeptidase of $H$. samuelpessoai was also determined by overlay gels, presenting a broad spectrum of $\mathrm{pH}$ (ranging from 5 to 10) and temperature (26 to $50^{\circ} \mathrm{C}$ ), showing maximum hydrolytic activity at $\mathrm{pH} 6.0$ at $37^{\circ} \mathrm{C}$ (Pereira et al. 2010a). These large spectra of $\mathrm{pH}$ and temperature retain maximum flexibility for the trypanosomatid to survive under different environmental conditions. In this sense, the surface leishmanolysinlike molecules of $H$. samuelpessoai cells participate in adhesive properties during the interaction with invertebrate gut (Pereira et al. 2010a) and mammalian macrophages (Pereira et al. 2010b). Other Herpetomonas species, including H. megaseliae and H. anglusteri, produce at least one metallopeptidase similar to the leishmanolysin, which is a conserved molecule with ancestral functions during the insect colonization. 
The $45 \mathrm{kDa}$ cysteine peptidase synthesized by H. samuelpessoai cells had its activity reduced during the parasite growth at $37^{\circ} \mathrm{C}$ in comparison to $26^{\circ} \mathrm{C}$, and when cultured up to $72 \mathrm{~h}$ in the presence of the differentiation-eliciting agent, dimethylsulfoxide. The modulation in the $45 \mathrm{kDa}$ cysteine peptidase expression is connected to the differentiation process, since both temperature and dimethylsulfoxide are able to trigger the promastigote into paramastigote transformation in H. samuelpessoai (Santos et al. 2003; Pereira et al. 2009). In contrast, the expression of leishmanolysin-like molecules was not modulated during the differentiation in H. samuelpessoai (Pereira et al. 2009, 2010b).

The cultivation of $H$. megaseliae and $H$. samuelpessoai in different growth media induced the production of distinct profiles of both cellular and extracellular peptidases as revealed by a simple inspection using substrate-SDS-PAGE (Branquinha et al. 1996; Santos et al. 2002, 2003; Nogueira de Melo et al. 2006). In addition, the incorporation of different proteinaceous substrates into SDS-PAGE allowed the identification of substrate specific proteolytic activity in a complex cellular extract. For example, cellular cysteine peptidase (115-100, 40 and $35 \mathrm{kDa})$ and metallopeptidase $(70$ and $60 \mathrm{kDa}$ ) activities of $\mathrm{H}$. megaseliae were detected in both casein and gelatin zymograms (Nogueira de Melo et al. 2006). Additionally, the use of casein in the gel revealed a distinct acidic metallopeptidase of $50 \mathrm{kDa}$ when the parasite was cultured in the modified Roitman's complex medium. However, no proteolytic activity was detected when hemoglobin was used as co-polymerized substrate (Nogueira de Melo et al. 2006).

\subsection{Proteases produced by Herpetomonas species: Taxonomic marker}

Insect trypanosomatids have been traditionally allocated to a number of genera that were described based on morphological features, host and geographical origin (Wallace et al. 1983; Momen, 2001). However, for identification purposes, these criteria proved to be impractical and insufficient, because the same trypanosomatid species may be recovered from diverse species of insects and the same insect species may harbor various species of trypanosomatids. In addition, the morphology of trypanosomatid cells can be modified by environmental factors (Podlipaev, 2001; Momen, 2001, 2002). Therefore, there is a need to develop more effective means of trypanosomatid identification. With this task in mind, the expression of proteolytic activities in the Trypanosomatidae family was explored as a potential marker to discriminate between the morphologically indistinguishable flagellates isolated from insects and plants (Branquinha et al. 1996; Santos et al. 1999, 2005, 2008). For instance, many trypanosomatids have been erroneously placed in the genus Herpetomonas or, conversely, many Herpetomonas spp. may remain hidden in other genera. Santos and coworkers (2005) proposed an additional tool for trypanosomatid identification, including species belonging to the Herpetomonas genus by using in situ detection of proteolytic activities on gelatin-SDS-PAGE, in association with specific peptidase inhibitors. The results showed that nine distinct Herpetomonas species $(H$. anglusteri, $H$. samuelpessoai, $H$. mariadeanei, $H$. roitmani, $H$. muscarum ingenoplastis, $H$. muscarum muscarum, $H$. megaseliae, $H$. dendoderi and Herpetomonas sp. isolated from the salivary gland of a phytophagous insect) produced species specific cellular peptidase profiles (Table 1), which can be useful in the correct identification of these parasites. The exception for this observation was seen in $H$. samuelpessoai and H. anglusteri, which presented a similar cell-associated proteolytic pattern. However, these two Herpetomonas species excreted distinct proteolytic activities, which may 
be a reflection of changes in the nutritional requirements during the life-cycle of the flagellates. Therefore, the authors infer that profiles of both cellular and extracellular peptidases represent an additional criterion to be used in the identification of trypanosomatids (Santos et al. 2005).

\begin{tabular}{|c|c|c|c|c|c|c|}
\hline \multirow[t]{2}{*}{$\begin{array}{l}\text { Herpetomonas } \\
\text { species }\end{array}$} & \multicolumn{2}{|c|}{ Host } & \multirow{2}{*}{$\begin{array}{l}\text { Predominant } \\
\text { evolutive stage in } \\
\text { culture }\end{array}$} & \multirow{2}{*}{$\begin{array}{c}\text { Number } \\
\text { of cell- } \\
\text { associated } \\
\text { peptidases }\end{array}$} & \multicolumn{2}{|c|}{$\begin{array}{l}\text { Molecular masses of } \\
\text { peptidases in } \mathrm{kDa}\end{array}$} \\
\hline & Family & Species & & & $\begin{array}{c}\text { Metallo- } \\
\text { peptidases }^{\mathrm{a}}\end{array}$ & $\begin{array}{c}\text { Cysteine } \\
\text { peptidases }^{\mathrm{b}}\end{array}$ \\
\hline $\begin{array}{l}\text { Herpetomonas } \\
\text { sp. }\end{array}$ & $\begin{array}{l}\text { Hemiptera: } \\
\text { Coreidae }\end{array}$ & Phthia picta & Promastigote & 4 & 72,60 & 45,40 \\
\hline H. anglusteri & $\begin{array}{c}\text { Diptera: } \\
\text { Sarcophagidae }\end{array}$ & $\begin{array}{l}\text { Liopygia } \\
\text { ruficornis }\end{array}$ & Promastigote & 2 & 60 & 45 \\
\hline H. dendoderi & $\begin{array}{l}\text { Diptera: } \\
\text { Culicidae }\end{array}$ & $\begin{array}{l}\text { Haemagogus } \\
\text { janthinomys }\end{array}$ & Promastigote & 5 & $130,110,95$ & 60,45 \\
\hline H. mariadeanei & $\begin{array}{l}\text { Diptera: } \\
\text { Muscidae }\end{array}$ & $\begin{array}{l}\text { Muscina } \\
\text { stabulans }\end{array}$ & Promastigote & 2 & $\mathrm{nd}^{\mathrm{c}}$ & 42,38 \\
\hline H. megaseliae & $\begin{array}{l}\text { Diptera: } \\
\text { Phoridae }\end{array}$ & $\begin{array}{l}\text { Megaselia } \\
\text { scalaris }\end{array}$ & Promastigote & 8 & $100,80,67,60$ & $95,45,40,35$ \\
\hline $\begin{array}{l}\text { H. muscarum } \\
\text { ingenoplastis }\end{array}$ & $\begin{array}{c}\text { Diptera: } \\
\text { Calliphoridae }\end{array}$ & $\begin{array}{l}\text { Phormia } \\
\text { regina }\end{array}$ & Promastigote & 2 & 80,67 & nd \\
\hline $\begin{array}{l}\text { H. muscarum } \\
\text { muscarum }\end{array}$ & $\begin{array}{l}\text { Diptera: } \\
\text { Muscidae }\end{array}$ & $\begin{array}{c}\text { Musca } \\
\text { domestica }\end{array}$ & Promastigote & 6 & 100,80 & $95,50,45,40$ \\
\hline H. roitmani & $\begin{array}{l}\text { Diptera: } \\
\text { Syrphidae }\end{array}$ & Ornidia obesa & Opisthomastigote & 1 & 50 & nd \\
\hline $\begin{array}{l}\text { H. } \\
\text { samuelpessoai }\end{array}$ & $\begin{array}{l}\text { Hemiptera: } \\
\text { Reduviidae }\end{array}$ & $\begin{array}{c}\text { Zelus } \\
\text { leucogrammus }\end{array}$ & Promastigote & 2 & 60 & 45 \\
\hline
\end{tabular}

a The metallopeptidase activities were completely blocked by $10 \mathrm{mM} \mathrm{1,10-phenanthroline.}$

${ }^{\mathrm{b}}$ The cysteine peptidases were inhibited by $10 \mu \mathrm{M}$ E-64.

c Non detected (nd).

Table 1. Peptidase profiles in different Herpetomonas species detected in gelatin-SDS-PAGE.

\subsection{Peptidase screening in Crithidia}

Among the insect trypanosomatids, the genus Crithidia comprises monoxenic trypanosomatids of insects that were originally characterized by the presence of choanomastigote forms in their life cycles (Hoare and Wallace, 1966). The first studies employing zymograms in order to detect proteolytic activity in Crithidia spp. were performed by Frank and Ashall in 1990. In the two studies published in that year, the activity in Crithidia fasciculata extracts was compared to T. cruzi. In this sense, it is worth mentioning that $C$. fasciculata, among all non-pathogenic trypanosomatid species, has been considered an excellent model organism for many studies concerning trypanosomatids, because it can be cultivated in high yields and do not require specific bio-safety precautions (Vickerman, 1994).

In a first approach (Ashall, 1990), parasite extracts were made by the use of $0.5 \%$ Nonidet P40 and mixed with SDS-PAGE sample buffer in non-denaturing conditions. After 
electrophoresis in SDS-PAGE, gels were overlaid with $0.75 \%$ agarose containing the chromogenic substrate Bz-Arg-pNA at $0.5 \mathrm{mM}$ and at $\mathrm{pH} 8.0$ and incubated for $4-6 \mathrm{~h}$ at $37^{\circ} \mathrm{C}$, and then photographed using a blue filter to reveal yellow bands containing $p$ nitroaniline. A single component with molecular mass $>200 \mathrm{kDa}$ that hydrolyzed this substrate was detected in C. fasciculata as well as in T. cruzi crude extracts. A modified procedure was also employed (Ashall et al. 1990), in which electrophoresis was followed by shaking the gels with $2 \%$ Triton X-100 and then the incubation of gels for $10 \mathrm{~min}$ in the presence of a range of amidomethylcoumarin substrates containing arginine adjacent to the amidomethylcoumarin moiety, at $\mathrm{pH}$ 8.0. Fluorescent bands were visualized in gels by ultraviolet light by the hydrolysis of each substrate. A single band of substrate hydrolysis occurred with all six substrates tested, in both $T$. cruzi and C. fasciculata, with the same electrophoretic mobility (150-200 kDa). Incubation of gel strips with various peptidase inhibitors showed that the enzyme was strongly inhibited by diisopropyl phosphorofluoridate (DFP), N- $\alpha$-tosyl-L-lysinyl-chloromethylketone (TLCK), leupeptin and a peptidyldiazomethane containing lysine at $\mathrm{P}_{1}$, but not by E-64, PMSF, pepstatin A, 1,10phenanthroline and a peptidyldiazomethane containing methionine at $\mathrm{P}_{1}$. This enzyme was characterized as an alkaline peptidase, probably from the serine-type, that cleaves peptide bonds on the carboxyl side of arginine residues at $\mathrm{pH} 8.0$ (Ashall, 1990).

Following this set of experiments, Etges (1992) employed surface radioiodination of living cells, fractionation by Triton X-114 extraction and phase separation, and zymogram analysis by fibrinogen-SDS-PAGE in order to describe the presence of a surface metallopeptidase in C. fasciculata with biochemical similarities to the gp63 from Leishmania spp. This peptidase is one of major surface molecules in all Leishmania species and play vital roles in the different stages of Leishmania life cycle, being suggested its participation in many aspects of the infection inside the mammalian host (Yao, 2010). The presence of a similar neutral-toalkaline metallopeptidase at the surface of $C$. fasciculata led to the suggestion that gp63 should not be involved in the infection of the mammalian host by Leishmania, but rather contributes to the survival of the trypanosomatid inside the digestive tract of the insect (Santos et al. 2006).

The work of Etges (1992) opened the possibility to use the same technique in order to analyze the proteolytic profiles in different members of distinct trypanosomatid genera. With this task in mind, our group has analyzed the proteolytic profiles of a great number of species from 8 different genera of trypanosomatids by the use of SDS-PAGE containing $0.1 \%$ co-polymerized gelatin as substrate (Branquinha et al. 1996; Santos et al. 2005; 2008). In those studies, it became clear that two distinct proteolytic activities can be detected in total cell lysates: cysteine- and metallopeptidases. For detection of cysteine peptidase activity, the optimal conditions were established to be an acidic $\mathrm{pH}$ value (5.0-6.0) and the presence of a reducing agent, such as DTT, which was essential for detection of this activity. The use of specific inhibitors, such as E-64, prevented the development of cysteine peptidase activity bands. Metallopeptidases were consistently observed in a broad $\mathrm{pH}$ range (5.0-10.0), and the zinc-chelator 1,10-phenanthroline completely inhibited their activity.

In our first work (Branquinha et al. 1996), three Crithidia species were studied: C. fasciculata, C. guilhermei and C. luciliae. Cells were lysed by the addition of SDS-PAGE sample buffer in non-denaturing conditions, and peptidases were characterized by electrophoresis on $7-15 \%$ gradient SDS-PAGE with $0.1 \%$ gelatin co-polymerized as substrate. Cell lysates of the three 
species produced similar patterns of proteolysis at $28^{\circ} \mathrm{C}$ : two cysteine peptidase bands in the 80-110 $\mathrm{kDa}$ range and a minor cysteine peptidase activity detected at $45 \mathrm{kDa}$; and a metallopeptidase band detected in the 55-66 kDa range. When cells were lysed with the nonionic detergent Triton X-114, cysteine peptidases were detected in the aqueous phase, whereas the metallopeptidase partitioned into the detergent-rich phase, which suggested that the latter is membrane-associated. Interestingly, cell lysates of these species were also employed by our group in another comparative study (Santos et al. 2005), in which a single cysteine peptidase was found at $50 \mathrm{kDa}$ and two metallopeptidases were detected at $70 \mathrm{kDa}$ and at $90 \mathrm{kDa}$. In the latter study, peptidases were analyzed in $10 \%$ linear polyacrylamide gels containing gelatin, and the temperature of incubation after electrophoresis was $37^{\circ} \mathrm{C}$. As explained by Martinez and Cazzulo (1992), the apparent molecular mass of each band varies depending on the experimental conditions, including acrylamide concentration and temperature of incubation, which may explain this discrepancy. Despite this fact, both studies highlighted the common proteolytic profile between these species, possibly reflecting their phylogenetic proximity.

Unlike the similarities detected in the three Crithidia spp. described above, heterogeneous proteolytic profiles were observed in different members of this genus. For instance, Crithidia acantocephali produced 4 cysteine peptidases of $80,75,70$ and $50 \mathrm{kDa}$, while Crithidia harmosa presented 3 metallopeptidases at 63,50 and $45 \mathrm{kDa}$ (Santos et al. 2005). These data suggested the value of proteolytic enzymes in distinguishing between trypanosomatid species that cannot be differentiated on structural grounds (Santos et al. 2005). In order to study the distribution of metallopeptidases in trypanosomatids, our group also investigated cellassociated proteolytic activities in distinct species by gelatin-SDS-PAGE in conditions that favor the detection of this subgroup, specifically alkaline conditions ( $\mathrm{pH} 9.0)$ and proteolytic inhibitors that putatively identified these enzymes, such as 1,10-phenanthroline (Santos et al. 2008). The analysis confirmed the previous results in all the species cited above, showing a great heterogeneity of expression of metallopeptidases not only in Crithidia spp. but in a wide range of trypanosomatids as well.

In a similar approach, our group described the differential expression of peptidases in endosymbiont-harboring Crithidia species in comparison to members of this genus that naturally lacks a bacterium in the cytoplasm (d'Avila-Levy et al. 2001). In this genus, the trypanosomatids Crithidia deanei, Crithidia desouzai and Crithidia oncopelti have been described to contain a bacterium symbiont in the cytoplasm, known as endosymbiont, which can be eliminated by the use of antibiotics, leading to the generation of cured strains (reviewed by De Souza and Motta, 1999). Gelatin-SDS-PAGE analysis was used to characterize the cell-associated and extracellular peptidases in these organisms, and our survey showed that a similar proteolytic profile was observed in cells of $C$. desouzai and in wild and cured strains of $C$. deanei: two cysteine peptidases migrating at $60-65 \mathrm{kDa}$ and two metallopeptidases at 51-58 $\mathrm{kDa}$. An additional cysteine peptidase was detected in wild strains at $100 \mathrm{kDa}$. A subsequent study from our group showed that, after Triton X-114 extraction preformed in $C$. deanei cells, a $65-\mathrm{kDa}$ cysteine peptidase partitioned exclusively in the aqueous phase, possibly present in intracellular compartments, and a 51-kDa metallopeptidase was only detected in the detergent-rich phase (d'Avila-Levy et al. 2003). The remaining enzymes, at $60 \mathrm{kDa}$ and at $58 \mathrm{kDa}$, which corresponds to a cysteine-type and to a metallo-type peptidase, respectively, were found in both aqueous and detergent-rich 
phases. In cells of C. oncopelti, two metallopeptidases were detected in 59-63 kDa range (d'Avila-Levy et al. 2001) (Figure 1).

The analysis of the spent culture medium showed a similar profile among the abovementioned species: $C$. desouzai and both strains of $C$. deanei displayed an 80-kDa cysteine peptidase and a $60-\mathrm{kDa}$ metallopeptidase, and $\mathrm{C}$. oncopelti showed four bands of protein degradation migrating at $101 \mathrm{kDa}, 92 \mathrm{kDa}, 76 \mathrm{kDa}$ and $59 \mathrm{kDa}$, all belonging to the metallopeptidase class. For comparison, C. fasciculata displayed a more complex extracellular profile, comprising five metallopeptidases migrating at $101 \mathrm{kDa}, 92 \mathrm{kDa}, 76$ $\mathrm{kDa}, 60 \mathrm{kDa}$ and $43 \mathrm{kDa}$ (d'Avila-Levy et al. 2001). In summary, the proteolytic profiles of $C$. deanei and C. desouzai are identical, and distinct from $C$. oncopelti, which is in accordance to a revision in Crithidia taxonomy proposed previously by Brandão et al. (2000) and d'AvilaLevy et al. (2004) and recently confirmed by molecular phylogenetic analyses (Teixeira et al. 2011). In this sense, this genus must be subdivided into three groups: the first one (Angomonas) must include $C$. deanei and $C$. desouzai, the second one (designated as Strigomonas) must include C. oncopelti and the remaining Crithidia spp. would remain in the originally described genus.

In the same work (d'Avila-Levy et al. 2001), the availability of $C$. deanei wild and cured strains allowed us to study whether the presence of the endosymbiont induces any alteration in the proteolytic profile. The absence of the cell-associated 100-kDa cysteine peptidase in the cured strain was the only qualitative difference found, and may possibly be related to the absence of the endosymbiont. In addition, the activity of extracellular peptidases was enhanced in the cured strain, which provides evidence that the presence of the endosymbiont diminishes the secretion of proteolytic enzymes, mainly the metallopeptidase (d'Avila-Levy et al. 2001).

Extracellular peptidases were also the focus of studies in some species belonging to the genus Crithidia. Unlike cell-associated enzymes, qualitative differences were observed when extracellular proteolytic enzymes were analyzed. In all the species tested, only metallopeptidases were detected, and 3 bands in the 60-80 kDa range were common to $C$. fasciculata, C. guilhermei and C. luciliae. Nevertheless, bands with lower molecular mass (30$40 \mathrm{kDa}$ ) were found exclusively in C. fasciculata, while higher molecular mass bands (90-100 kDa) were only detected in C. fasciculata and C. guilhermei (d'Avila-Levy et al. 2001; Santos et al. 2005). Interestingly, the extracellular proteolytic profile of $C$. luciliae was also analyzed by Jaffe and Dwyer (2003), but only two metallopeptidases were detected at $97 \mathrm{kDa}$ and at 50 $\mathrm{kDa}$, which could be explained by the smallest amount of spent culture medium employed as well as by the reduced incubation period for proteolysis development.

Melo et al. (2002) characterized the extracellular peptidases from C. guilhermei through the incorporation of different protein substrates into SDS-PAGE. When cells were grown in yeast extract-peptone-sucrose medium, the extracellular proteolytic zymogram comprised four bands with gelatinolytic activity migrating at $80 \mathrm{kDa}, 67 \mathrm{kDa}, 60 \mathrm{kDa}$ and $55 \mathrm{kDa}$. All bands were inhibited by 1,10-phenanthroline, which classified these enzymes as metallopeptidases, and these gelatinases remained active over a broad $\mathrm{pH}$ range, being the maximum activity reached at $\mathrm{pH} 5.0$, which is in accordance to their proper activity in the insect gut. Interestingly, these enzymes were mainly detected at $37^{\circ} \mathrm{C}$; when gels were incubated at $28^{\circ} \mathrm{C}$, which corresponds to the room temperature and to the expected value in the insect gut, the proteolytic activity was reduced and the 55-kDa band was not detected, 
possibly reflecting the adaptations of the parasite to the different environments it might confront during its life cycle. Besides the gelatinolytic activity, the 60-, 67- and 80-kDa bands were also able to degrade casein incorporated into SDS-PAGE, but with minor activity, and no proteolytic activity was detected when bovine serum albumin incorporated into the gel. A distinct pattern of degradation was observed when hemoglobin was used as substrate: a 43-kDa metallopeptidase was exclusively detected in these conditions. These hemoglobinases are possibly involved in supplying exogenous iron and heme for the parasite.

Besides the characterization of these peptidases when C. guilhermei cells were grown in yeast extract-peptone-sucrose medium, log-phase cells grown in different culture medium composition were obtained and analyzed. The proteolytic zymograms displayed no qualitative difference, only quantitative variations. In this sense, the replacement of sucrose by glucose enhanced the proteolytic activity of the four bands, while either the replacement of sucrose by glycerol or the cultivation of cells in BHI decreased the proteolytic detection. These results pointed out to the influence of the culture medium composition in the production of extracellular peptidases in this microorganism (Melo et al. 2002).

\section{Two-dimensional zymography coupled to peptidase identification through mass spectrometry: Possibilities and technical difficulties}

For decades, one-dimensional (1D) zymographic gel systems have been broadly used for the analysis and characterization of proteolytic activities in several organisms. Especially in protozoa parasites, this technique has been extensively useful to detect and identify peptidases involved in virulence of pathogenic protozoa (North and Coombs 1981; Coombs and North 1983; Lockwood et al. 1987; Williams and Coombs 1995; Cuervo et al. 2006; De Jesus et al, 2009). Also, through this technique, crucial roles of these enzymes during the cell cycle of parasites have been revealed (Brooks et al. 2001; De Jesus et al. 2007). In the postgenomic era, this methodology is shedding light on the biochemical traits of organisms of unknown genomes (Santos et al. 2005; Pereira et al. 2009; d'Avila-Levy et al. 2001), and has the potential of increasing the functional annotation of the genome for those organisms yet sequenced. However, information regarding on isoforms of proteolytic enzymes, isoelectric point of peptidases, and even a higher resolution of complex proteolytic profiles cannot be obtained by $1 \mathrm{D}$ zymographic systems. In superior eukaryotes, a broader analysis of functional peptidases has been achieved by combining zymographic techniques with proteomic technologies, specifically two-dimensional electrophoresis (2D) and mass spectrometry that enable a better resolution of peptidase arranges and the direct identification of peptidase species (Ong and Chang 1997; Park et al. 2002; Zhao and Russell 2003; Wilkesman and Schröder 2007; Lee et al. 2011). Nevertheless, this combined approach has been little used in the study of protozoan parasites (De Jesus et al. 2009).

Proteomic approaches intend to produce the widest possible resolution of individual proteins from a protein mixture, followed by protein identification by mass spectrometry (MS). The fractionation of complex cellular extracts by $2 \mathrm{D}$ is attained by combining two independent electrophoretic separations, the isoelectric focusing (IEF) in the first dimension and SDS-PAGE in the second dimension (MacGillivray and Rickwood 1974; O'Farrell 1975). After, protein spots are excised from the gel, submitted to enzymatic digestion and the resulting peptides are analyzed by MS. The developments of soft ionization sources for 
protein MS analysis, such as matrix-assisted laser desorption/ionization (MALDI) and electrospray ionization (ESI) enabled the reliable identification of proteins (Karas and Hillenkamp, 1988; Tanaka et al. 1988; Fenn et al. 1989). In this way, the combination of MALDI or ESI with several different mass analyzers and increasingly powerful bioinformatics tools allows the identification of thousands protein components from a complex biological sample. Although protein identification relies on genome sequences data, several algorithms based on homology analyses yet permit to identify proteins of organisms with unknown genomes (Shevchenko et al. 2001; Waridel et al. 2007). The expressive contribution of 2D and MS approaches to the understanding of several aspects of the biology of protozoan parasites such as pathogenic trypanosomatids has been recently reviewed (Cuervo et al. 2010). In these parasites, proteomics studies have contributed to catalogue global protein profiles, provide experimental evidence for gene expression, reveal changes in protein expression during development, assign potential functions to the hypothetical proteins, elucidate the subcellular localization, and determine potential drug and vaccine targets (Cuervo et al. 2010, 2011). Despite all the advantages of 2D, the determination of enzymatic activity in this technique is hampered due to the use of chaotropic agents and additional denaturant components present in the sample buffer used for IEF.

The potentialities of both approaches, i. e., the capability to resolve complex protein mixtures by $2 \mathrm{D}$ and the capability to reveal functional (active) peptidases by zymography are merged in the two-dimensional zymography (2DZ) methodology (Figure 6). This technique, coupled with mass spectrometry for protein identification make possible the broader mapping of active proteolytic enzymes present in a protein extract (Zhao et al. 2004; De Jesus et al. 2009; Saitoh et al. 2007; Paes-Leme et al. 2009; Larocca et al. 2010; Lee et al. 2011). Two main strategies are used for $2 \mathrm{DZ}$ analysis: the first one consist on the separation of protein sample by $2 \mathrm{DZ}$ or $2 \mathrm{D}$ reverse zymography in parallel with separation by denaturing or non-denaturing 2D followed by staining with MS compatible stain. After migration, the comparison and overlapping of both gel images, using appropriated gel image analysis software, allow the assigning of proteolytic spots to protein spots which are carefully excised from the gel and further identified by MS (Métayer et al. 2002; Park et al. 2002; Choi et al. 2004; Taiyoji et al. 2009; Lee et al. 2011). Using this strategy our group identified active cysteine peptidases in whole extracts of the two Trichomonas vaginalis isolates exhibiting high and low virulence phenotypes (De Jesus et al. 2007) (Figure 6). Whole extracts analyzed by 2DZ gels showed both qualitative and quantitative differences in the cysteine peptidase spots between the isolates. According to the $\mathrm{pH}$ distribution across the gel strip, proteolytic spots displayed $\mathrm{p} I$ values between 4.2 and 6.5 , a biochemical characteristic that cannot be obtained from 1DZ. It was also observed that the qualitative and quantitative differences in the cysteine peptidases (CP) expression revealed by 2DZ may be related to the virulence pattern of the $T$. vaginalis isolate (Figure 6). After identification of the active "cysteine peptidase fingerprint" expressed by each T. vaginalis isolate by tandem MS analysis (MS/MS) it was corroborated that distinct isoforms of CP4 are expressed between the isolates, specifically differentiated by a change in one amino acid of a main peptide. Whereas low-virulence parasites expressed NSWGTAWGEK-containing CP4 isoforms, the virulent isolate expressed a NSWGTTWGEK-containing CP4 isoform (De Jesus et al. 2007). The NSWGTTWGEK-containing CP4 isoform is present in several virulent isolates, is secreted and can induce apoptosis in the epithelial cells (Sommer et al. 2005; De 
Jesus et al. 2007). Another important contribution of 2DZ analysis in this work was to reveal that only a limited number of active gelatinase-CPs are expressed in vitro, which contrast to a high number of $\mathrm{CP}$ genes present in the parasite genome. Alternatively, the employment of different substrates may reveal other peptidase activities. Additionally, in this work, 2DZ allowed preliminary mapping of active forms of low-abundance CPs, which are not easily visualized in 2D Coomassie-stained gels (De Jesus et al. 2007).

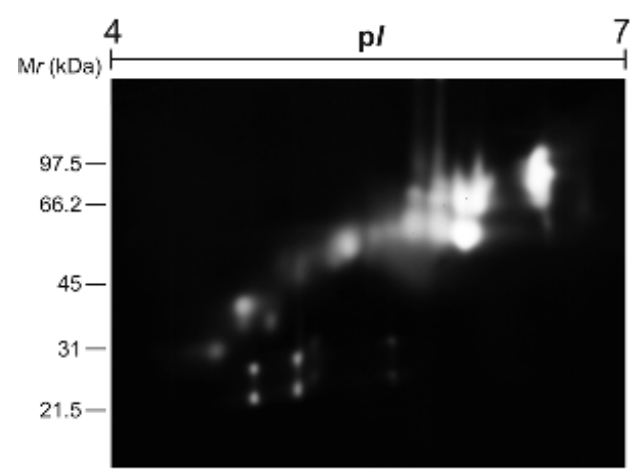

A

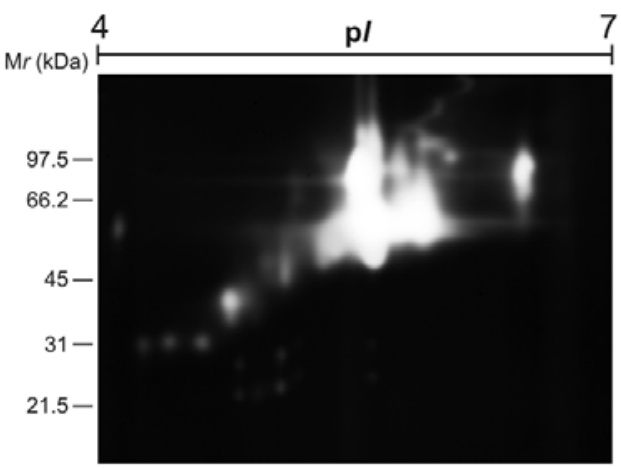

C

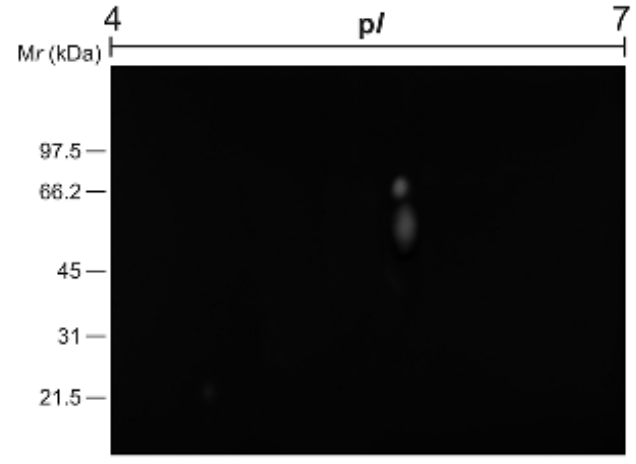

B

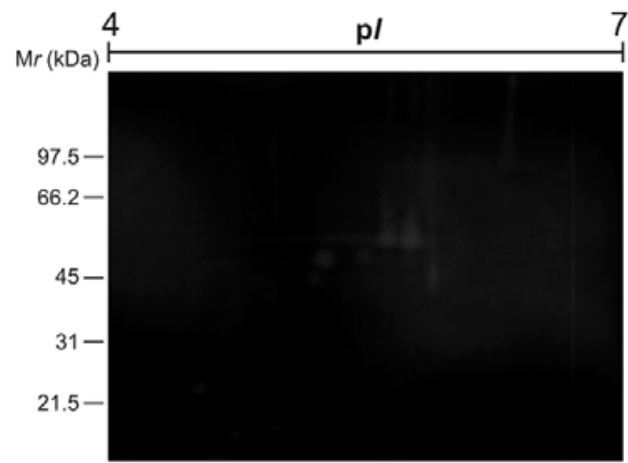

D

Fig. 6. Two-dimensional-substrate gel electrophoresis showing the profiles of active cysteine peptidase detected in whole extracts of Trichomonas vaginalis isolates displaying low (A, B) and high $(C, D)$ virulence phenotypes. Assays were performed in the absence $(A, C)$ or presence $(B, D)$ of cysteine peptidase inhibitor E-64. For experimental details see De Jesus et al., 2009. Reprinted with permission of Journal of Proteome Research.

The second strategy consists on the electrophoretic separation in SDS-substrate gels and direct MS analysis from 2DZ gels. However, the major challenge of this approach consists on having "to fish" a specific protein in a "protein sea". To overcome this drawback, fluorescent substrates are used (Zhao et al 2004; Thimon et al. 2008). Proteins are separated by $2 \mathrm{D}$, gels are further incubated with fluorescent peptide substrate and the emitted fluorescence is observed under an UV transilluminator. As the substrate is not embedded in the gel, it can be easily washed, and the protein spot can be excised from the gel for MS/MS analysis. It is clear that the 2DZ-MS techniques should be preceded by broad biochemical 
characterization of the proteolytic profile of the organism as suggested in the flowchart (Figure 1). The use of 2DZ approaches combined with MS/MS analysis might be a shortcut in the identification of the active degradome and, associated to conventional 2D mapping, might allow the identification of active and inactive peptidases without the use of specific antibodies or laborious purification methods.

\section{Conclusion}

Substrate-SDS-PAGE has been described in 1980 by Heussen and Dowdle, 30 years after description of this technique, several and important advances in methodological approaches to unveil biological systems have been achieved, such as automated DNA sequencing and protein identification through mass spectrometry just to cite a few. In spite of this, this simple and inexpensive methodology still provides powerful and unique information about peptidases. In organisms with complete genome sequences, bioinformatic analysis provides rich information on putative peptidases, however, it cannot be ascertained if the ORFs are indeed expressed and active. It is common to observe an elevated number of putative peptidases in the organisms' genome, with a limited number of active peptidases. While in organisms without genome information, this technique allows the detection and assessment of several biochemical characteristics of the enzymes, such as preferable $\mathrm{pH}$, temperature, catalytic type and substrate preference. Finally, two-dimensional zymography coupled with mass spectrometry for protein identification make possible the broader mapping of active proteolytic enzymes present in a protein extract, allowing the detection of distinct isoforms of peptidases differentiated by a single change in one amino acid of a main peptide. Therefore, thirty years after its first description, zymography still is a powerful approach to unveil peptidases.

\section{References}

Ashall, F. (1990). Characterisation of an alkaline peptidase of Trypanoma cruzi and other trypanosomatids. Molecular and Biochemical Parasitology Vol.38, No.1, pp.77-87.

Ashall, F., Harris, D., Roberts, H., Healy, N. \& Shaw, E. (1990). Substrate specificity and inhibitor sensitivity of a trypanosomatid alkaline peptidase. Biochimica et Biophysica Acta Vol.1035, pp. 293-299.

Bouvier, J., Etges, R., \& Bordier, C. (1987). Identification of the promastigote surface protease in seven species of Leishmania. Molecular and Biochemical Parasitology Vol. 24, pp. 7379.

Brandão, A.A., Miranda, A., Degrave, W.M. \& Sousa, M.A. (2000). The heterogeneity of choanomastigote-shaped trypanosomatids as analyzed by their kDNA minicircle size: taxonomic implications. Parasitology Research Vol.86, pp. 809-812.

Branquinha, M.H., Vermelho, A.B., Goldenberg, S. \& Bonaldo, M.C. (1996). Ubiquity of cysteine- and metalloproteinase in a wide range of trypanosomatids. Journal of Eukaryotic Microbiology Vol.43, pp. 131-135.

Breganó, J.W., Picão, R.C., Graça, V.K., Menolli, R.A., Jankevicius, S.I., Filho, P.P. \& Jankevicius, J.V. (2003). Phytomonas serpens, a tomato parasite, shares antigens with Trypanosoma cruzi that are recognized by human sera and induce protective immunity in mice. FEMS Immunology and Medical Microbiology Vol.39, pp. 257-264. 
Brooks, D.R., Denise, H., Westrop, G.D., Coombs, G.H. \& Mottram, J.C. (2001). The stageregulated expression of Leishmania mexicana $\mathrm{CPB}$ cysteine proteases is mediated by an intercistronic sequence element. The Journal of Biological Chemistry Vol. 276, pp. 47061-47069.

Cadavid-Restrepo, G., Gastardelo, T.S., Faudry, E., de Almeida, H., Bastos, I.M., Negreiros, R.S., Lima, M.M., Assumpção, T.C., Almeida, K.C., Ragno, M., Ebel, C., Ribeiro, B.M., Felix, C.R. \& Santana, J.M. (2011). The major leucyl aminopeptidase of Trypanosoma cruzi (LAPTc) assembles into a homohexamer and belongs to the M17 family of metallopeptidases. BMC Biochemistry Vol. 12, pp. 46.

Chicharro, C. \& Alvar, J. (2003). Lower trypanosomatids in HIV/AIDS patients. Annual Tropical Medical Parasitology Vol.97, pp. 75-80.

Choi, N.S., Yoo, K.H., Yoon, K.S., Maeng, P.J. \& Kim, S.H. (2004). Nano-scale proteomics approach using two-dimensional fibrin zymography combined with fluorescent SYPRO ruby dye. Journal of Biochemistry and Molecular Biology Vol.37, pp. 298-303.

Coombs, G.H. \& North, M.J. (1983). An analysis of the proteinases of Trichomonas vaginalis by polyacrylamide gel electrophoresis. Parasitology Vol.86, pp. 1-6.

Cuervo, P., Sabóia-Vahia, L., Costa Silva-Filho, F., Fernandes, O., Cupolillo, E., D \& Jesus, J.B. (2006). A zymographic study of metalloprotease activities in extracts and extracellular secretions of Leishmania (Viannia) braziliensis strains. Parasitology Vol. 132, pp. 177-185.

Cuervo, P., Domont, G.B. \& De Jesus, J.B. (2010). Proteomics of trypanosomatids of human medical importance. Journal of Proteomics Vol.10, pp. 845-867.

Cuervo, P., Fernandes, N. \& de Jesus, J.B. (2011). A proteomics view of programmed cell death mechanisms during host-parasite interactions. Journal of Proteomics Vol. 75, pp. 246-256.

d'Avila-Levy, C.M., Melo, A.C.N., Vermelho, A.B. \& Branquinha, M.H. (2001). Differential expresson of proteolytic enzymes in endosymbiont-harboring Crithidia species. FEMS Microbiology Letters, Vol.202, pp. 73-77.

d'Avila-Levy, C.M., Souza, R.F., Gomes, R.C., Vermelho, A.B. \& Branquinha, M.H. (2003). A metalloproteinase extracellularly released by Crithidia deanei. Canadian Journal of Microbiology Vol.49, pp. 625-632.

d'Avila-Levy, C.M., Araújo, F.M., Vermelho, A.B., Branquinha, M.H., Alviano, C.S., Soares, R.M. \& Santos, A.L.S. (2004). Differential lectin recognition of glycoproteins in choanomastigote-shaped trypanosomatids: taxonomic implications. FEMS Microbiol Lett. Vol. 231, pp. 171-176.

d'Avila-Levy, C.M., Araújo, F.M., Vermelho, A.B., Soares, R.M., Santos, A.L.S. \& Branquinha, M.H. (2005). Proteolytic expression in Blastocrithidia culicis: influence of the endosymbiont and similarities with virulence factors of pathogenic trypanosomatids. Parasitology Vol. 130, pp. 413-420.

d'Avila-Levy, C.M., Volotão, A.C.C., Araújo, F.M., De Jesus, J.B., Motta, M.C.M., Vermelho, A.B., Santos, A.L.S. \& Branquinha, M.H. (2009). Bodo sp., a free-living flagellate, expresses divergent proteolytic activities from the closely related parasitic trypanosomatids. The Journal of Eukaryotic Microbiology Vol. 56, pp. 454-458.

De Jesus, J.B., Cuervo, P., Junqueira, M., Britto, C., Silva-Filho, F.C., Soares, M.J., Cupolillo, E., Fernandes, O. \& Domont, G.B. (2007). A further proteomic study on the effect of iron in the human pathogen Trichomonas vaginalis. Proteomics Vol. 7, pp. 1961-1972. 
De Jesus, J.B., Cuervo, P., Britto, C., Sabóia-Vahia, L., Costa E Silva-Filho, F., Borges-Veloso, A., Barreiros Petrópolis, D., Cupolillo, E. \& Barbosa Domont, G. (2009). Cysteine peptidase expression in Trichomonas vaginalis isolates displaying high- and lowvirulence phenotypes. Journal of Proteome Research Vol. 8, pp. 1555-1164.

De Souza, W. \& Motta, M.C.M. (1999). Endosymbiosis in protozoa of the Trypanosomatidae family. FEMS Microbiology Letters Vol.173, No.1, pp. 1-8.

Devel, L., Rogakos, V., David, A., Makaritis, A., Beau, F., Cuniasse, P., Yiotakis, A.\& Dive, V. (2006). Development of selective inhibitors and substrate of matrix metallo proteinase-12. Journal of Biological Chemistry Vol. 281, pp. 11152-11160.

Elias, C.G.R., Pereira, F.M., Silva, B.A., Alviano, C.S., Soares, R.M.A. \& Santos, A.L.S. (2006). Leishmanolysin (gp63 metallopeptidase)-like activity extracellularly released by Herpetomonas samuelpessoai. Parasitology Vol.132, pp. 37-47.

Elias, C.G.R., Pereira, F.M., Dias, F.A., Silva, T.L., Lopes, A.H., d'Avila-Levy, C.M., Branquinha, M.H. \& Santos, A.L.S. (2008). Cysteine peptidases in the tomato trypanosomatid Phytomonas serpens: influence of growth conditions, similarities with cruzipain and secretion to the extracellular environment. Experimental Parasitology Vol. 120, pp. 343-352.

Etges, R. (1992). Identification of a surface metalloproteinase on 13 species of Leishmania isolated from humans, Crithidia fasciculata and Herpetomonas samuelpessoai. Acta Tropica Vol.50, pp. 205-217.

Fenn, J., Mann, M., Meng, C.K., Wong, S.F. \& Whitehouse, C.M. (1989). Electrospray ionization for mass spectrometry of large biomolecules. Science Vol. 246, pp. 64-71.

Grellier, P., Vendeville, S., Joyeau, R., Bastos, I.M., Drobecq, H., Frappier, F., Teixeira, A.R., Schrével J, Davioud-Charvet E, Sergheraert C \& Santana JM. (2001). Trypanosoma cruzi prolyl oligopeptidase Tc80 is involved in nonphagocytic mammalian cell invasion by trypomastigotes. Journal of Biological Chemistry Vol. 276, pp. 4707847086.

Heussen, C. \& Dowdle, E.B. (1980). Electrophoretic analysis of plasminogen activators in polyacrylamide gels containing sodium dodecyl sulphate and copolymerized substrates. Analytical Biochemistry Vol. 102, pp. 196-202.

Hoare, C.A. \& Wallace, F.G. (1966). Developmental stages of trypanosomatid flagellates: a new terminology. Nature, Vol.212, pp. 1385-1386.

Jaffe, C.L. \& Dwyer, D.M. (2003). Extracellular release of the surface metalloprotease, gp63, from Leishmania and insect trypanosomatids. Parasitology Research Vol.91, pp. 229-37.

Karas, M. \& Hillemkamp, F. (1988). Laser desorption ionization of proteins with molecular masses exceeding 10000 kDa. Analytical Chemistry Vol. 60, pp. 2299-2301.

Kupai, K., Szucs, G., Cseh, S., Hajdu, I., Csonka, C., Csont, T. \& Ferdinandy, P. (2010). Matrix metalloproteinase activity assays: Importance of zymography. Journal of Pharmacological and Toxicological Methods Vol. 61, pp. 205-209.

Laemmli, U.K. (1970). Cleavage of structural proteins during the assembly of the head of bacteriophage T4. Nature Vol. 227, pp. 680-685.

Larocca, M., Rossano, R. \& Riccio, P. (2010). Analysis of green kiwi fruit (Actinidia deliciosa $\mathrm{cv}$. Hayward) proteinases by two-dimensional zymography and direct identification of zymographic spots by mass spectrometry. Journal of the Science of Food and Agriculture Vol. 90, pp. 2411-248. 
Lee, K.J., Kim, J.B., Ha, B.K., Kim, S.H., Kang, S.Y., Lee, B.M. \& Kim, D.S. (2011). Proteomic characterization of Kunitz trypsin inhibitor variants, Tia and Tib, in soybean [Glycine max (L.) Merrill]. Amino Acids, in press.

Lockwood, B.C., North, M.J., Scott, K.I., Bremner, A.F. \& Coombs, G.H. (1987). The use of a highly sensitive electrophoretic method to compare the proteinases of trichomonads. Molecular and Biochemical Parasitology Vol. 24, pp. 89-95.

Lopes, J.D., Caulada, Z., Barbieri, C.L. \& Camargo, E.P. (1981). Cross-reactivity between Trypanosoma cruzi and insect trypanosomatids as a basis for the diagnosos of Chagas' disease. American Journal of Tropical Medicine and Hygine Vol.30, pp. 11831188.

MacGillivray, A.J. \& Rickwood, D. (1974). The heterogeneity of mouse-chromatin nonhistone proteins as evidenced by two-dimensional polyacrylamide-gel electrophoresis and ion-exchange chromatography. European Journal of Biochemistry Vol. 41, pp. 181-190.

Martinez, J. \& Cazzulo, J.J. (1992). Anomalous electrophoretic behaviour of the major cysteine proteinase (cruzipain) from Trypanosoma cruzi in relation to its apparent molecular mass. FEMS Microbiology Letters Vol.74, pp. 225-229.

McGhee, R.B. \& Cosgrove, W.B. (1980). Biology and physiology of the lower Trypanosomatidae. Microbiology Reviews Vol.44, pp. 140-173.

Melo, A.C.N., d'Avila-Levy, C.M., Branquinha, M.H. \& Vermelho, A.B. (2002). Crithidia guilhermei: gelatin- and haemoglobin-degrading extracellular metalloproteinases. Experimental Parasitology Vol.102, pp. 150-156.

Métayer, S., Dacheux, F., Dacheux, J.L. \& Gatti, J.L. (2002). Comparison, characterization, and identification of proteases and protease inhibitors in epididymal fluids of domestic mammals. Matrix metalloproteinases are major fluid gelatinases. Biology of Reproduction Vol. 66, pp. 1219-1229.

Michaud, D., Cantin, L., Raworth, D.A. \& Vrain, T.C. (1996). Assessing the stability of cystatin/cysteine proteinase complexes using mildly-denaturing gelatinpolyacrylamide gel electrophoresis. Electrophoresis Vol.17, pp. 74-79.

Momen, H. (2001). Some current problems in the systematics of trypanosomatids. International Journal for Parasitology Vol.31, pp. 640-642.

Momen, H. (2002). Molecular taxonomy of trypanosomatids: some problems and pitfalls. Archives of Medical Research Vol.33, pp. 413-415.

Morio, F., Reynes, J., Dollet, M., Pratlong, F., Dedet, J.P. \& Ravel, C. (2008). Isolation of a protozoan parasite genetically related to the insect trypanosomatid Herpetomonas samuelpessoai from a human immunodeficiency virus positive patient. Jounal of Clinical Microbiology Vol.46, pp. 3845-3847.

Nogueira de Melo, A.C., d'Avila-Levy, C.M., Dias, F.A., Armada, J.L.A., Silva, H.D., Lopes, A.H.C.S., Santos, A.L.S., Branquinha, M.H. \& Vermelho, A.B. (2006). Peptidases and gp63-like proteins in Herpetomonas megaseliae: possible involvement in the adhesion to the invertebrate host. International Journal for Parasitology, Vol.36, pp. $415-422$.

North, M.J. \& Coombs, G.H. (1975). Proteinases of Leishmania mexicana amastigotes and promastigotes: analysis by gel electrophoresis. Molecular and Biochemical Parasitology Vol. 3, pp. 293-300. 
O'Farrell, P.H. (1975). High resolution two-dimensional electrophoresis of proteins. The Journal of Biological Chemistry Vol. 250, pp. 4007-4021.

Ong, K.L. \& Chang, F.N. (1997). Analysis of proteins from different phase variants of the entomopathogenic bacteria Photorhabdus luminescens by two-dimensional zymography. Electrophoresis Vol. 18, pp. 834-839.

Paes Leme, A.F., Kitano, E.S., Furtado, M.F., Valente, R.H., Camargo, A.C., Ho, P.L., Fox, J.W. \& Serrano, S.M. (2009). Analysis of the subproteomes of proteinases and heparin-binding toxins of eight Bothrops venoms. Proteomics Vol. 9, pp. 733-745.

Park, S.G., Kho, C.W., Cho, S., Lee, D.H., Kim, S.H. \& Park, B.C. (2002). A functional proteomic analysis of secreted fibrinolytic enzymes from Bacillus subtilis 168 using a combined method of two-dimensional gel electrophoresis and zymography. Proteomics. Vol. 2, pp. 206-211.

Pereira, F.M., Elias, C.G., d'Avila-Levy, C.M., Branquinha, M.H. \& Santos, A.L.S. (2009). Cysteine peptidases in Herpetomonas samuelpessoai are modulated by temperature and dimethylsulfoxide-triggered differentiation. Parasitology, Vol.136, pp. 45-54.

Pereira, F.M., Dias, F.A., Elias, C.G., d'Avila-Levy, C.M., Silva, C.S., Santos-Mallet, J.R., Branquinha, M.H. \& Santos, A.L.S. (2010a). Leishmanolysin-like molecules in Herpetomonas samuelpessoai mediate hydrolysis of protein substrates and interaction with insect. Protist Vol.161, pp. 589-602.

Pereira, F.M., Santos-Mallet, J.R., Branquinha, M.H., d'Avila-Levy, C.M. \& Santos, A.L.S. (2010b). Influence of leishmanolysin-like molecules of Herpetomonas samuelpessoai on the interaction with macrophages. Microbes and Infection Vol.12, pp. 1061-170.

Podlipaev, S. (2001). The more insect trypanosomatids under study-the more diverse Trypanosomatidae appears. International Journal for Parasitology Vol.31, pp. 648-652.

Rawlings, N.D., Barrett, A.J. \& Bateman, A. (2010). MEROPS: the peptidase database. Nucleic Acids Research. Vol. 38, pp. D227-D233.

Saitoh, E., Yamamoto, S., Okamoto, E., Hayakawa, Y., Hoshino, T., Sato, R., Isemura, S., Ohtsubo, S. \& Taniguchi, M. (2007). Identification of cysteine proteases and screening of cysteine protease inhibitors in biological samples by a twodimensional gel system of zymography and reverse zymography. Analytical Chemistry Insights Vol. 18, pp. 51-59.

Santos, A.L.S., Ferreira, A., Franco, V.A., Alviano, C.S. \& Soares, R.M.A. (1999). Characterization of proteinases in Herpetomonas anglusteri and Herpetomonas roitmani. Current Microbiology Vol.39, pp. 61-64.

Santos, A.L.S., Abreu, C.M., Alviano, C.S. \& Soares, R.M.A. (2002). Activation of the glycosylphosphatidylinositol anchored membrane proteinase upon release from Herpetomonas samuelpessoai by phospholipase C. Current Microbiology Vol.45, pp. 293-298.

Santos, A.L.S., Batista, L.M., Abreu, C.M., Alviano, C.S., Angluster, J. \& Soares, R.M.A. (2001). Developmentally regulated protein expression mediated by dimethylsulfoxide in Herpetomonas samuelpessoai. Current Microbiology Vol.42, pp. 111-116.

Santos, A.L.S., Rodrigues, M.L., Alviano, C.S., Angluster, J. \& Soares, R.M.A. (2003). Herpetomonas samuelpessoai: dimethylsulfoxide-induced differentiation is influenced by proteinase expression. Current Microbiology Vol.46, pp. 11-17. 
Santos, A.L.S., Abreu, C.M., Alviano, C.S. \& Soares, R.M.A. (2005). Use of proteolytic enzymes as an additional tool for trypanosomatid identification. Parasitology Vol.130, pp. 79-88.

Santos, A.L.S., Branquinha, M.H. \& d'Avila-Levy, C.M. (2006). The ubiquitous gp63-like metalloprotease from lower trypanosomatids: in the search for a function. Anais da Academia Brasileira de Ciências Vol.78, pp. 687-714.

Santos, A.L.S., d'Avila-Levy, C.M., Elias, C.G.R., Vermelho, A.B. \& Branquinha, M.H. (2007). Phytomonas serpens: immunological similarities with the human trypanosomatid pathogens. Microbes and Infection Vol.9, pp. 915-921.

Santos, A.L.S., Soares, R.M.A., Alviano, C.S. \& Kneipp, L.F. (2008). Heterogeneous production of metallo-type peptidases in parasites belonging to the family Trypanosomatidae. European Journal of Protistology Vol.44, pp.103-113.

Schneider, P. \& Glaser, T. A. (1993). Characterization of a surface metalloprotease from Herpetomonas samuelpessoai and comparison with Leishmania major promastigote surface protease. Molecular and Biochemical Parasitology Vol.58, pp. 277-282.

Shevchenko, A., Sunyaev, S., Loboda, A., Shevchenko, A., Bork, P., Ens, W. \& Standing, K.G. (2001). Charting the proteomes of organisms with unsequenced genomes by MALDI-quadrupole time-of-flight mass spectrometry and BLAST homology searching. Analytical Chemistry Vol.73, pp. 1917-1926.

Sommer, U., Costello, C.E., Hayes, G.R., Beach, D.H., Gilbert, R.O., Lucas, J.J. \& Singh, B.N. (2005). Identification of Trichomonas vaginalis cysteine proteases that induce apoptosis in human vaginal epithelial cells. Journal of Biological Chemistry Vol. 280, pp. 23853-23860.

Snoek-van Beurden, P.A. \& Von den Hoff, J.W. (2005). Zymographic techniques for the analysis of matrix metalloproteinases and their inhibitors. Biotechniques. Vol. 38, pp. 73-83.

Taiyoji, M., Shitomi, Y., Taniguchi, M., Saitoh, E. \& Ohtsubo, S. (2009). Identification of proteinaceous inhibitors of a cysteine proteinase (an Arg-specific gingipain) from Porphyromonas gingivalis in rice grain, using targeted-proteomics approaches. Journal of Proteome Research Vol. 8, pp. 5165-5174.

Tanaka, K., Waki, H., Ido, Y., Akita, S., Yoshida, Y. \& Yoshida, T. (1988). Protein and polymer analyses up to $\mathrm{m} / \mathrm{z} 100000$ by laser ionization time-of-flight mass spectrometry. Rapid Communications in Mass Spectrometry Vol. 2, pp.151-153.

Teixeira, M.M., Borghesan, T.C., Ferreira, R.C., Santos, M.A., Takata, C.S., Campaner, M., Nunes, V.L., Milder, R.V., de Souza, W. \& Camargo, E.P. (2011). Phylogenetic validation of the genera Angomonas and Strigomonas of trypanosomatids harboring bacterial endosymbionts with the description of new species of trypanosomatids and of proteobacterial symbionts. Protist Vol.162, pp. 503-524.

Thimon, V., Belghazi, M., Labas, V., Dacheux, J.L. \& Gatti, J.L.(2008). One- and twodimensional SDS-PAGE zymography with quenched fluorogenic substrates provides identification of biological fluid proteases by direct mass spectrometry. Analytical Biochemistry Vol. 375, pp. 382-384.

Vickerman, K. (1994). The evolutionary expansion of the trypanosomatid flagellates. The International Journal for Parasitology, Vol.24, pp. 1317-1331.

Wallace, F.G. (1966). The trypanosomatid parasites of insects and arachnids. Experimental Parasitology Vol. 18, pp. 124-193. 
Wallace, F.G., Camargo, E.P., McGhee, R.B. \& Roitman, I. (1983). Guidelines for the description of new species of lower trypanosomatids. Journal of Protozoology Vol.30, pp. 308-313.

Waridel, P., Frank, A., Thomas, H., Surendranath, V., Sunyaev, S., Pevzner, P. \& Shevchenko, A. (2007). Sequence similarity-driven proteomics in organisms with unknown genomes by LC-MS/MS and automated de novo sequencing. Proteomics. Vol. 7, pp. 2318-2329.

Wilder, C.L., Park, K., Keegan, P.M. \& Platt, M.O. (2011). Manipulating substrate and pH in zymography protocols selectively distinguishes cathepsins $\mathrm{K}, \mathrm{L}, \mathrm{S}$, and V activity in cells and tissues. Archives of Biochemistry and Biophysics Vol. 516, pp. 52-77.

Williams, A.G. \& Coombs, G.H. (1995). Multiple protease activities in Giardia intestinalis trophozoites. The International Journal of Parasitology Vol. 25, pp. 771-778.

Wilkesman, J.G. \& Schröder, H.C. (2007). Analysis of serine proteases from marine sponges by 2-D zymography. Electrophoresis Vol. 28, pp. 429-436.

Yao, C. (2010). Major surface protease of trypanosomatids: one size fits all? Infection and Immunity Vol.78, pp. 22-31.

Zhao, Z. \& Russell, P.J. (2003). Trypsin activity assay in substrate-specific one- and twodimensional gels: a powerful method to separate and characterize novel proteases in active form in biological samples. Electrophoresis Vol. 24, pp. 3284-3248.

Zhao, Z., Raftery, M.J., Niu, X.M., Daja, M.M. \& Russell, P.J. (2004). Application of in-gel protease assay in a biological sample: characterization and identification of urokinase-type plasminogen activator (uPA) in secreted proteins from a prostate cancer cell line PC-3. Electrophoresis Vol. 25, pp. 1142-1148. 


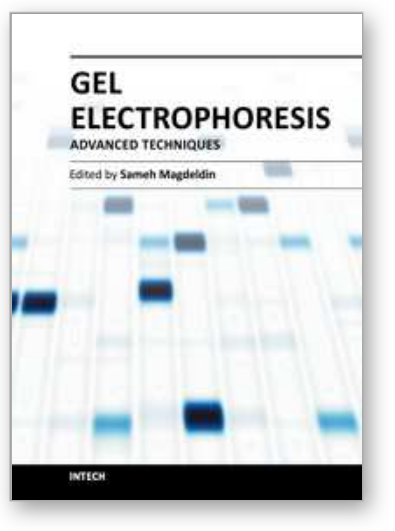

\author{
Gel Electrophoresis - Advanced Techniques \\ Edited by Dr. Sameh Magdeldin
}

ISBN 978-953-51-0457-5

Hard cover, 500 pages

Publisher InTech

Published online 04, April, 2012

Published in print edition April, 2012

As a basic concept, gel electrophoresis is a biotechnology technique in which macromolecules such as DNA, RNA or protein are fractionated according to their physical properties such as molecular weight or charge. These molecules are forced through a porous gel matrix under electric field enabling uncounted applications and uses. Delivered between your hands, a second book of this Gel electrophoresis series (Gel Electrophoresis- Advanced Techniques) covers a part, but not all, applications of this versatile technique in both medical and life science fields. We try to keep the contents of the book crisp and comprehensive, and hope that it will receive overwhelming interest and deliver benefits and valuable information to the readers.

\title{
How to reference
}

In order to correctly reference this scholarly work, feel free to copy and paste the following:

Claudia M. d'Avila-Levy, André L. S. Santos, Patrícia Cuervo, José Batista de Jesus and Marta H. Branquinha (2012). Applications of Zymography (Substrate-SDS-PAGE) for Peptidase Screening in a Post-Genomic Era, Gel Electrophoresis - Advanced Techniques, Dr. Sameh Magdeldin (Ed.), ISBN: 978-953-51-0457-5, InTech, Available from: http://www.intechopen.com/books/gel-electrophoresis-advanced-techniques/applications-ofzymography-substrate-sds-page-for-peptidase-screening-in-a-post-genomic-era

\section{INTECH}

open science | open minds

\section{InTech Europe}

University Campus STeP Ri

Slavka Krautzeka 83/A

51000 Rijeka, Croatia

Phone: +385 (51) 770447

Fax: +385 (51) 686166

www.intechopen.com

\section{InTech China}

Unit 405, Office Block, Hotel Equatorial Shanghai

No.65, Yan An Road (West), Shanghai, 200040, China 中国上海市延安西路65号上海国际贵都大饭店办公楼405单元

Phone: +86-21-62489820

Fax: $+86-21-62489821$ 
(C) 2012 The Author(s). Licensee IntechOpen. This is an open access article distributed under the terms of the Creative Commons Attribution 3.0 License, which permits unrestricted use, distribution, and reproduction in any medium, provided the original work is properly cited. 